\title{
Korpusová analýza jazykové přesnosti v písemném projevu studentů angličtiny jako cizího jazyka ${ }^{1}$
}

\author{
František Tůma \\ Technická univerzita v Liberci, Fakulta př́rodovědně-humanitní a pedagogická, \\ Katedra anglického jazyka
}

Redakci zasláno 16. 10. 2012 / upravená verze obdržena 19. 12. 2012 / k uveřejnění přijato 6. 1.2013

\begin{abstract}
Abstrakt: $\mathrm{V}$ této studii prezentujeme dílčí výsledky výzkumu z oblasti didaktiky cizích jazyků, ve kterém bylo využito analýzy žákovského korpusu. Hlavní výzkum se zaměřoval na rozvoj komunikační kompetence v oblasti psaní v tzv. blended learning kurzu u vysokoškolských neoborových studentů angličtiny jako cizího jazyka. Ve studii nejdříve stručně konceptualizujeme procesy rozvíjení komunikační kompetence a poté se zaměřujeme na měření výsledků těchto procesů $\mathrm{v}$ oblasti jazykové přesnosti. Výzkumný soubor tvořilo 18 studentů v kurzu angličtiny na úrovni A2 dle $S E R R J$ (2002), kteří participovali ve třech diskusních úkolech provedených v online prostředí za použití asynchronního diskusního fóra. Projektování diskusí vycházelo ze sociálně-konstruktivistických teorií učení. Hlavním výzkumným nástrojem byl žákovský korpus založený na textech napsaných studenty ve dvou online diskusích. Výsledky ukázaly, že se u studentů celková úroveň komunikační kompetence v oblasti psaní zvýšila. Zjištění vyplývající z analýzy korpusu zaměřené na jazykovou přesnost se ovšem jeví v některých oblastech jako ne zcela průkazná. Výsledky výzkumu naznačují, že jazyková přesnost studentů souvisela s vyjadřovaným obsahem. Studie ukazuje možné využití žákovských korpusů ve výzkumu zaměřeného na jazykovou přesnost a upozorňuje na některá jejich omezení.
\end{abstract}

Klíčová slova: žákovský korpus, komunikační kompetence, jazyková přesnost, blended learning, sociálně-konstruktivistické teorie učení

\section{1 Úvod}

Cílem cizojazyčné výuky je (mimo jiné) rozvíjet komunikační kompetenci u studentů. Proto je nezbytné klást důraz na to, aby studenti používali cizí jazyk

1 Tento příspěvek je součástí výstupů grantu SGS FP TUL č. 5842/2012 Využití blended learning v terciálním vzdělávání pro rozvoj komunikačních dovedností v anglickém jazyce. Autor děkuje docentce Michaele Píšové, dvěma anonymním recenzentům a členům redakční rady za cenné podněty a připomínky.

DOI: $10.5817 /$ PedOr2013-1-92 
pro vzájemnou interakci. Ve výzkumném projektu (Tůma, 2012), jehož dílčí výsledky zde představujeme, jsme pro písemnou interakci studentů použili informační a komunikační technologie (ICT), konkrétně diskusní fórum. Zkoumali jsme, zda a k jakým změnám došlo u studentů v jejich komunikační kompetenci $\mathrm{v}$ dovednosti psaní. $\mathrm{V}$ této studii se zaměřujeme na výsledky související se změnami v jazykové přesnosti.

Jazyková přesnost, kterou v této studii chápeme jako míru výskytu chyb, patří k důležitým aspektům ústního i písemného projevu. Vzhledem $\mathrm{k}$ tomu, že písemný projev u studentů byl ve výzkumném šetření rozvíjen pouze prostřednictvím online interakce, zajímalo nás, zda tato interakce vedla $\mathrm{k}$ rozvoji jazykové přesnosti písemného projevu u studentů, tedy zda došlo ke změnám komunikační kompetence studentů v dovednosti psaní.

Ke zjištění těchto změn jsme použili tzv. žákovský korpus (angl. learner corpus, Granger, 2008; Šebesta, 2012a; Štindlová, 2011). Žákovské korpusy chápeme jako soubory promluv studentů, které jsou založené na přirozené elicitaci $^{2}$ a které většinou bývají opatřeny anotací. Abychom mohli chybovost systematicky zkoumat, je třeba korpus anotovat, tedy např́íklad označit jazykové chyby.

Jak jsme uvedli výše, tato studie zkoumá změny $v$ jazykové přesnosti v psaní u studentů v kurzu, který využívá ICT. V nedávné rešerši českých pedagogických časopisů a analýze zaměřené na studie zabývající se ICT ve vzdělávání (Tůma, v tisku) jsme zjistili, že v empirických studiích z let 2006 až 2011 nebylo běžné analyzovat výsledky procesů učení. Navíc se zdá, že aplikace ICT zakotvené $\mathrm{v}$ sociálně-konstruktivistických teoriích nejsou $\mathrm{v}$ českém pedagogickém výzkumu časté a v tomto směru patrně není využito potenciálu, který ICT nabízí.

Předkládaná studie tedy přispívá $\mathrm{k}$ poznání $\mathrm{v}$ oblasti využívání ICT v cizojazyčné výuce tím, že zkoumá změny ve vybraných oblastech jazykové přesnosti u studentů pomocí analýzy žákovského korpusu.

\section{Teoretická východiska}

Vzhledem k šiŕi východisek pro náš výzkum a omezenému prostoru pro tento příspěvek se zde omezíme pouze na stěžejní teorie související s komunikační

2 Přirozeně elicitovanou promluvou rozumíme takovou promluvu, která byla zachycena během reálné situace, při níž bylo cílem mluvčího dosáhnout určité komunikační potřeby (k dalším způsobům elicitace viz Ellis \& Barkhuizen, 2005, s. 15-50; k autenticitě projevu studentů viz také Šebesta, 2012b). 
kompetencí, s učením se prostřednictvím interakce s druhými a s konceptem jazyková přesnost. Dále uvedeme východiska pro koncepci a realizaci výzkumu a pro měření změn v komunikační kompetenci.

\subsection{Didaktická východiska}

Jedním z cílů výuky cizího jazyka je rozvíjení komunikační kompetence studentů. $\mathrm{V}$ našem výzkumu vycházíme $\mathrm{z}$ Bachmanova modelu komunikační kompetence $(1990)^{3}$. Tento model charakterizuje jednotlivé komponenty komunikační kompetence, $\mathrm{z}$ nichž je pro následný výklad klíčová především její strategická, gramatická a pragmatická komponenta. Strategická komponenta zajištuje plánování, realizaci a vyhodnocování komunikačního procesu. Gramatická komponenta ${ }^{4}$ se skládá z jazykových prostředků (tedy pravopisu, výslovnosti, gramatiky, slovní zásoby; zajištuje tedy především výběr a uspořádání jazykových forem $\mathrm{v}$ promluvě), zatímco pragmatická komponenta zajištuje vhodné a efektivní použití jazykových forem v určitých situacích. Na těchto charakteristikách gramatické a pragmatické komponenty komunikační kompetence můžeme osvětlit dva odlišné, avšak komplementární, pohledy na jazyk - strukturní a funkční (Schiffrin, 1994), které v této studii představují především východiska pro anotaci žákovského korpusu, a proto je stručně představíme. Strukturní pohled na jazyk, vycházející ze strukturalismu, popisuje, jak jsou jazykové tvary tvořeny a jak spolu souvisejí. Analýza vycházející ze strukturního pohledu na jazyk typicky nejprve rozloží text na strukturní jednotky (obvykle věty) a následně zkoumá vztahy mezi nimi. Naproti tomu funkční pohled na jazyk začíná zkoumáním funkce, kterou jazyková forma $v$ řeči plní. $V$ této souvislosti se uvádí pojem jazyková funkce, která představuje komunikační záměr mluvčího v dané situaci. Jedna část pragmatické komponenty komunikační kompetence je tvořena právě jazykovými funkcemi.

Osvojování a upevňování jazykových prostředků a rozvoj řečových dovedností, ke kterým dochází prostřednictvím interakce mezi studenty, vysvětlujeme sociálně-konstruktivistickými teoriemi učení (Bertrand, 2003, s. 153-178). Na těchto teoriích je částečně založeno i kooperativní učení a vyučování

3 O výběru, úskalích a specifikách tohoto modelu jsme, stejně jako o souvisejících lingvistických konceptech a teoriích, podrobně diskutovali jinde (Tůma, 2012, s. 21-31).

4 V jiných modelech, např. ve Společném evropském referenčním rámci (SERRJ, 2002), bývá tato komponenta označována jako lingvistická, v Bachmanově modelu však figuruje označení gramatická. 
(Johnson \& Johnson, 1994; Kasíková, 2007). S nimi jsou v souladu i některé zásadní teorie osvojování cizího jazyka, zejména tzv. input hypothesis (Krashen, 1981) akcentující roli srozumitelného vstupu (angl. comprehensible input) pro procesy osvojování jazyka oproti procesům vědomého učení se, a také tzv. interaction hypothesis, ve které Long (1996) vyzdvihuje roli dorozumívání se o významu (angl. negotiation of meaning) během interakce. Patří sem i tzv. output hypothesis (Swain, 2000) zdůrazňující, že pro osvojování cizího jazyka je důležité produkovat takové promluvy, které jsou srozumitelné pro ostatní.

Zmíněné pojetí komunikační kompetence (a s ním související pohledy na jazyk) a uvedené teorie učení a teorie osvojování cizího jazyka tvoří dva základní pilíře didaktických východisek výuky psaní, která byla podrobena zkoumání. Konkrétně se jedná o (post-) komunikační přístup k výuce cizích jazyků (Choděra, 2006, s. 95-98; Richards \& Rodgers, 2001, s. 153-177) a z něho vycházející vyučování jazyka formou úkolů5 (angl. task-based language teaching; Ellis, 2003; Nunan, 2004; Skehan, 1998; Willis, 1996).

$\mathrm{Z}$ hlediska realizace výuky jsme $v$ rámci blended learning kurzu ${ }^{6}$ navrhli a rozpracovali koncept online diskusního úkolu, který vychází z přístupu k vyučování jazyka formou úkolů (angl. task-based language teaching). V online diskusním úkolu je klíčová jeho hlavní komunikační část, tj. samotná diskuse, která je v našem pojetí realizována formou asynchronního diskusního fóra7. Metodiku implementace a řízení diskuse stejně jako výhody diskuse na online fóru a její specifika jsme podrobně rozpracovali jinde (Tůma, 2012, s. 66-94).

\subsection{Východiska pro koncepci a realizaci výzkumu}

Cílem navržených online diskusních úkolů bylo rozvíjet komunikační kompetenci v psaní. Obsahem byla diskuse na dané téma. Činnost studujících spočívala v jejich aktivním zapojení do diskuse, a tedy interakci s ostatními (srov. s input hypothesis, interaction hypothesis a output hypothesis). Inter-

5 V tomto didaktickém př́stupu je klíčový úkol, který studenti plní. Typicky se jedná o komunikační úkol, kterému předchází expozice cílovému jazyku (např̀ poslech rodilých mluvčích vykonávajících podobný úkol). Po vlastním komunikačním úkolu může následovat řada různě zaměřených pre-komunikačních aktivit, které jsou zaměřené např. na výuku nových jazykových prostředků nebo na opravu chyb z vlastního komunikačního úkolu.

$6 \quad$ Blended learning je kombinací výuky ve tř́dě s výukou online (Graham, 2006).

7 Jedná se o formu komunikace na internetu, kdy jednotliví účastníci mohou přispívat z různých míst (např z domova) a v různou dobu, tedy ne nutně současně. Jinou formou asynchronní komunikace je napr. email. 
vencí do procesu rozvoje komunikační kompetence je tedy samotná účast v diskusním fóru.

V tuto chvíli je nutné zmínit, že uvedená intervence byla navržena pro kurz angličtiny jako cizího jazyka na úrovni A2 (SERRJ, 2002), jedná se tedy o mírně pokročilou úroveň. Úspěšnost této intervence tedy byla měřena $\mathrm{s}$ ohledem na tuto úroveň. Přiměřenost obsahu (tedy volba témat) se rovněž odvíjela od popisu této úrovně. Pro specifikaci cílů jazyková úroveň A2 znamená především to, že studující mají omezený rozsah jazykových funkcí a jazykových prostředků (SERRJ, 2002; van Ek \& Trim, 1991).

Pro posouzení toho, zda bylo daného cíle dosaženo, lze použít koncept mezijazyka (angl. interlanguage), který lze charakterizovat jako oddělený jazykový systém, na jehož existenci usuzujeme z pozorovatelných pokusů studenta produkovat cílový jazyk (Selinker, 1984, s. 35; srov. Štindlová, 2011, s. 17-18). Samotný projev studentů bývá charakterizován pomocí trojice pojmů složitost, přesnost a plynulost projevu (angl. complexity, accuracy, fluency; Housen \& Kuiken, 2009), z nichž (jazyková) přesnost je pro tuto studii ústřední.

K přesnosti projevu (a s ní souvisejícím chybám) je nutné dodat, že samotný koncept chyby není jednotný (k tomu např. Brown, 2000, s. 215-240; Hrdlička, 2012). Chybu chápeme jako odchylku od jazykové normy, jejíž výběr je však také problematickýg. Kromě toho např. Ellis a Barkhuizen (2005, s. 59) upozorňují, že za chybu lze považovat nejen takové tvary, které jsou lingvisticky nesprávné, ale i nevhodné pro danou situaci, čímž poukazují na pragmatickou složku komunikační kompetence. Zde je třeba upozornit, že na úrovni A2 (SERRJ, 2002) je pragmatická komponenta značně omezená, nebot' základní jazykové funkce jsou vyjádřeny zpravidla velmi omezeným počtem již tak neutrálních frází (srov. van Ek \& Trim, 1991). Toto je reflektováno i v deskriptorech produkce (jak ústní, tak i písemné) ve Společném evropském referenčním rámci pro jazyky (2002), kde ani v rovině jednotlivých řečových dovedností, aniv rovině jednotlivých složek komunikační kompetence (včetně její sociolingvistické složky) na úrovni A2 není uvedeno, že má uživatel jazyka

Konkrétně existují různé variety angličtiny, např́íklad standardní britská angličtina, standardní americká angličtina atd. Kromě toho se setkáváme s fenoménem English as a Lingua Franca (Seidlhofer, 2009), kdy je angličtina používána jako médium pro dorozumění mezi mluvčími, pro které není angličtina mateřským jazykem. Vymezení normy je zde tedy problematické, protože mluvčí nejsou zpravidla nuceni používat jazyk jako rodilí mluvčí a jejich projev typicky nese znaky mateřského jazyka. 
jazykové prostředky používat vhodně pro danou situaci (srov. Lightbown \& Spada, 2006, s. 100-104). Na této úrovni tedy nelze pojednávat o vhodnosti používání cizího jazyka.

Toto představuje jedno ze základních východisek pro následnou analýzu chyb, ve které se zaměřujeme především na chyby strukturní (viz kapitola 3.4). I tak je však rozbor chyb studujících důležitý. Například Brown (2000, s. 231-233) nebo Lightbown a Spada (2006, s. 80) poukazují na to, že absence zpětné vazby na jazykovou přesnost může mít za následek tzv. fosilizaci, což je stav, kdy jsou určité jazykové chyby permanentní součástí projevu studujícího. Přitom přesnost je jednou $\mathrm{z}$ podmínek $\mathrm{k}$ dosažení vyšších referenčních úrovní (SERRJ, 2002).

V oblasti produktivních řečových dovedností lze Bachmanovo pojetí (1990) komunikační kompetence, specificky její strategickou komponentu ${ }^{9}$, konkretizovat výčtem mikro- a makro-dovedností pro psaní a mluvení (např. Brown, 2003, s. 142-143, 221). Ačkoliv se uvádí, že počítačem zprostředkovaná komunikace kombinuje aspekty psaného a mluveného jazyka (Crystal, 2011, s. 21, 31-32), z hlediska strategické kompetence odpovídají strategie uplatňované při přispívání do diskusního fóra spíše psaní, proto tuto interakci chápeme pro potřeby našeho výzkumu jako psaní ${ }^{10}$. Na základě uvedené konceptualizace rozvíjíme dovednost psaní (resp. makro-dovednosti související s dovedností psaní) zapojením studentů do online diskusních úkolů.

\subsection{Měření komunikační kompetence v psaní pomocí online diskusních úkolů}

Na úroveň nebo změnu kompetence, která je svým charakterem implicitní, lze usuzovat pouze z jazykových dat, která studenti produkují (tedy z performance, Ellis \& Barkhuizen, 2005, s. 6). Úroveň komunikační kompetence u studenta lze tedy určit na základě standardizovaných testů (Stern, 1983, s. 337-359) a lze na ni usuzovat na základě měření složitosti, přesnosti a plynulosti projevu (Ellis \& Barkhuizen, 2005; Housen \& Kuiken, 2009). Předpokládáme, že z hlediska přesnosti budou studenti při dosahování vyšší úrovně používat jazyk ve srovnatelném úkolu podobně přesně nebo přesněji (srov. SERRJ, 2002, s. 116).

9 Strategická kompetence zaujímá v Bachmanově modelu komunikační kompetence (1990) ústřední pozici a je „zodpovědná“ za vyhodnocení situace a v návaznosti na to za přípravu a realizaci komunikace.

10 Tento pohled podrobněji analyzujeme jinde (Tůma, 2012, s. 56-59, 102-104). 
Jak jsme již uvedli v úvodu studie, pro zkoumání přesnosti jsme použili analýzu žákovského korpusu sestávajícího z promluv studentů zachycených při jejich online interakci $v$ rámci kurzu. Při zkoumání přesnosti můžeme vycházet z chybové analýzy (Ellis \& Barkhuizen, 2005, s. 51-72), která se do korpusové lingvistiky promítá různými př́stupy k chybové anotaci (Štindlová, 2011), tedy, zjednodušeně řečeno, k značkování chyb v projevech studentů.

V žákovských korpusech, které jsou zatím k dispozici, převládá sice angličtina jako cílový jazyk, avšak tyto korpusy jsou kompilované z textů produkovaných studenty na pokročilých úrovních (rešerši a analýzu existujících žákovských korpusů provedla např. Štindlová, 2011), což potvrzuje i Granger (2008, s. 264). Zdá se tedy, že pro angličtinu na úrovni A2 (SERRJ, 2002) nemáme $\mathrm{k}$ dispozici žákovský korpus. Analýza námi připraveného korpusu tedy umožní rozširríit poznání nejen v oblasti procesů osvojování a učení se anglického jazyka na mírně pokročilé úrovni, ale také v oblasti cizojazyčné výuky s použitím online diskusních úkolů.

\section{Výzkumné šetření}

Hlavním cílem provedeného empirického výzkumu bylo zjistit změny v různých aspektech komunikační kompetence u studentů po jejich účasti v online diskusních úkolech. $V$ následujícím textu představíme především metody sběru a analýzy dat ve světle výzkumu jazykové přesnosti a z nich plynoucí zjištění.

\subsection{Kontext a účastníci}

Výzkum byl uskutečněn $v$ kurzu obecného anglického jazyka pro nefilology na Fakultě přírodovědně-humanitní a pedagogické při Technické univerzitě v Liberci. Cílová úroveň kurzu byla A2 (SERRJ, 2002). Tento dvousemestrální kurz probíhal formou blended learning, tedy kombinací výuky ve třídě (1x 90 minut týdně) a online. Tři online diskusní úkoly proběhly v rámci online komponenty kurzu v letním semestru akademického roku 2010/11, pro který byli studenti rozděleni do pěti- až šestičlenných online skupin. V každé skupině se v prvním úkolu měli studenti představit a najít vlastnosti a věci, které mají ve skupině společné; ve třetím úkolu studenti představili své plány na letní prázdniny a hledali společné prázdninové aktivity. Srovnatelnost prvního a třetího úkolu spočívala $\mathrm{v}$ délce diskuse, předpokládaném zapojení (požadovaný minimální počet příspěvků do fóra), konvergentním 
charakteru obou diskusí, př́itomnosti společného výstupu a přiměřenosti diskutovaných témat úrovni A2 (SERRJ, 2002, s. 59-64). Na základě výše uvedené konceptualizace byl kurz navržen tak, aby výuka psaní (tedy rozvoj makro-dovedností psaní) probíhala pouze v rámci online diskusních úkolů, jiná komponenta kurzu dovednost psaní přímo nerozvíjela.

Podle výsledků pre-testů (viz níže) bylo pro výzkumné šetření vybrán soubor 18 studentů ( 15 žen a 3 muži ve věku 21 až 31 let). Všichni vybraní účastníci absolvovali v předchozím semestru první část jazykového kurzu, ve které se seznámili s prací online, čímž bylo minimalizováno riziko zkreslení výsledků nedostatečnou připraveností používat ICT.

\subsection{Výzkumné otázky}

Celý výzkumný projekt měl za cíl zodpovědět pět výzkumných otázek souvisejících se zapojením studentů do online diskusních úkolů a z toho plynoucími změnami ve vybraných aspektech jejich komunikační kompetence. Konkrétně jsme se zabývali celkovou úrovní komunikační kompetence, syntaktickou složitostí jazykového projevu studentů, rozsahem jazykových funkcí, vnímanou plynulostí projevu a přesností projevu (Tůma, 2012). V této studii se zaměřujeme pouze na jazykovou přesnost. Výzkumná otázka tedy zní: Změnila se přesnost studentů v psaní během kurzu? Pokud ano, jak?

\subsection{Metodologie výzkumu}

Hlavnímu výzkumnému šetření předcházela pilotáž, ve které byly navržené výzkumné nástroje ověřeny a dále adaptovány pro potřeby výzkumu. Níže představujeme výzkumný design a metody sběru a analýzy dat.

Vlastní výzkumné šetření zahrnovalo různé zdroje pro sběr dat, z nichž jsou pro tuto studii relevantní dva: (a) didaktický test a (b) texty psané studenty v prvním a třetím diskusním úkolu. Didaktický test byl uplatněn na začátku a na konci kurzu a jeho návrh zohledňoval potřebu objektivně zhodnotit úroveň komunikační kompetence studentů především v oblasti psaní. Byla využita modifikovaná verze standardizovaných testů Key English Test, které odpovídají úrovni A2 (SERRJ, 2002). Výzkumný soubor tvořili studenti, jejichž výsledek pre-testu byl v rozmezí 55 až 85 \%. Jedná se tedy o studenty se vstupní úrovní mírně nižší než plně rozvinutá A2 (SERRJ, 2002), pro něž byl hlavně kurz navržen a u nichž se předpokládalo, že na konci kurzu dosáhnou plně rozvinuté úrovně A2 (SERRJ, 2002). Co se týče prvního a třetího dis- 
kusního úkolu, z textů psaných studenty byl zkompilován žákovský korpus, jehož anotace je představena níže. Sled a provázanost uvedených dvou metod jsou znázorněny na obrázku 1.

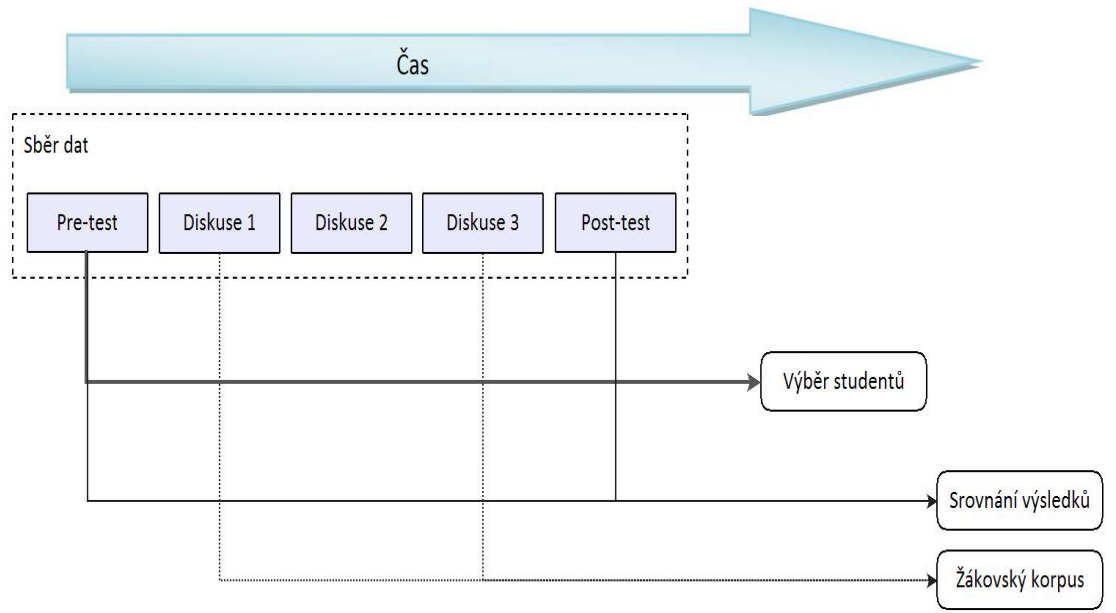

Obrázek 1. Sled a provázanost metod sběru dat.

Metody analýzy dat zahrnovaly vyhodnocení testů a anotaci žákovského korpusu dvěma hodnotiteli. Nejkomplikovanější metodou, která byla pro účely práce vyvinuta, byla anotace žákovského korpusu, kterou blíže představíme.

\subsection{Anotace žákovského korpusu}

Východiskem pro návrh anotačního schématu byly poznatky z korpusové lingvistiky, počítačem zprostředkované komunikace, strukturní a funkční pohled na jazyk a funkční a chybová analýza. $V$ této studii se zaměříme především na chybovou anotaci, jíž předcházela segmentace korpusu. Kromě toho níže stručně specifikujeme anotaci jazykových funkcí, která výsledky chybové analýzy doplňuje a je nezbytná pro interpretaci výsledků.

Prvním krokem při anotaci byla segmentace korpusu, která vycházela ze strukturního pojetí jazyka a kterou pro potřeby této studie stručně předsta- 
víme ${ }^{11}$. Promluvy studentů byly rozděleny na klauze (věty v rámci souvětí) a podle toho, zda takto vytvořené segmenty obsahovaly či neobsahovaly slovesnou frázi, byly označeny jako větný, resp. nevětný, materiál (Biber et al., 1999, s. 120). V této studii se budeme dále zabývat pouze větným materiálem.

Druhým krokem byla chybová anotace, která byla založena na chybové analýze. Jed notlivé segmenty větného materiálu byly nejdříve rekonstruovány, tedy $\mathrm{v}$ případě, že se vymykaly cílové jazykové normě, byly doplněny o správný jazykový tvar. Poté byl každý originální a rekonstruovaný segment porovnán. $\mathrm{V}$ případě shody byl tento segment považován za jazykově správný, $\mathrm{v}$ opačném případě byl opatřen chybovou anotací, která vycházela z porovnání originálního a rekonstruovaného segmentu.

Ačkoliv se v našem případě jednalo o situaci, kdy spolu v angličtině komunikovali rodilí mluvčí češtiny (podle Seidlhofer /2009/ se tedy jedná o situaci English as a Lingua Franca), měřili jsme chybovost jazyka studentů ve vztahu ke standardní britské angličtině tak, jak je popsána v aktuálních gramatikách a slovnících ${ }^{12}$. Co se týče pravopisu, za chybu jsme nepovažovali tvary, které byly v souladu se standardní americkou angličtinou.

Neprováděli jsme však celkovou anotaci všech chyb, ale pouze anotaci chyb ve vybraných oblastech (jedná se tedy o částečnou chybovou anotaci, viz Štindlová, 2011, s. 80). Chyby jsme klasifikovali podle jiné anotace (Dagneaux, Denness, \& Granger, 1998), kterou jsme modifikovali pro potřeby našeho výzkumu. Chybové oblasti a typy chyb jsme identifikovali pouze pro slovesné fráze v rámci větného materiálu. Anotační schéma zahrnovalo tyto oblasti gramatické kompetence: chyby ve formě (ortografie), v morfologii (flexe, slovesný čas, pomocné sloveso, komplexní morfologická chyba) a lexikální chyby (nevhodně použité slovo na základě významu). Kromě toho byly anotovány syntaktické chyby (chyba $v$ pořádku slov ve větě), které se vztahovaly k celému segmentu, nikoliv jen ke slovesné frázi. Tato typologie chyb je znázorněna $\mathrm{v}$ tabulce 1 , kde je také doplněna prŕklady z korpusu. Tučně jsou uvedeny chybné tvary, v závorce je uveden správný tvar.

11 Anotace korpusu byla pro účely hlavního výzkumu složitější, avšak některé její komponenty nejsou pro tuto studii př́mo relevantní, proto je zde neuvádíme. Pro kompletní anotaci viz Tůma (2012).

12 K této volbě nás vedla řada důvodů, mezi něž patří zatím ne zcela široce akceptovaná definice přesnosti v rámci English as a Lingua Franca, specifika cílové skupiny, cílová úroveň kurzu a také specifika počítačem zprostředkované komunikace. 
Tabulka 1

Typy chyb v chybové anotaci

\begin{tabular}{|c|c|c|}
\hline Oblast & Typ chyby & Příklad \\
\hline Písemná forma & Ortografická chyba & What doas he do? (does) \\
\hline \multirow[t]{4}{*}{ Morfologie } & Flexe & $\begin{array}{l}\text { He study archeology. } \\
\text { (studies) }\end{array}$ \\
\hline & Slovesný čas & $\begin{array}{l}\text { My hobbies are: watching } \\
\text { Tv, sleeping, but mainly } \\
\text { sports. I'm playing volleyball, } \\
\text { floorball and tennis. (I play) }\end{array}$ \\
\hline & Pomocné sloveso & $\begin{array}{l}\text { Where are you live? (Where } \\
\text { do you live?) }\end{array}$ \\
\hline & $\begin{array}{l}\text { Komplexní morfologická } \\
\text { chyba }\end{array}$ & $\begin{array}{l}\text { This year he is graduation at } \\
\text { university in Prague. (is going } \\
\text { to graduate) }\end{array}$ \\
\hline Lexikum & $\begin{array}{l}\text { Nevhodně použité slovo na } \\
\text { základě jeho významu }\end{array}$ & $\begin{array}{l}\text { Now i can't remind exactly } \\
\text { the name of part of the most } \\
\text { beautiful part of Spain. } \\
\text { (remember) }\end{array}$ \\
\hline Syntax & Chyba v pořádku slov & $\begin{array}{l}\text { For me is this topic very hard } \\
\text { (...this topic is...) }\end{array}$ \\
\hline
\end{tabular}

Pozn.: Př́́klady chyb vycházejí prrímo z korpusu.

Třetím krokem anotace bylo přidání jazykových funkcí jednotlivým segmentům na základě funkční analýzy. Tato analýza probíhala prostřednictvím přiřazování funkce na základě formy (Ellis \& Barkhuizen, 2005, s. 120-125), což znamená, že na základě vybraných formálních znaků (např. typ věty, použitý čas, použité modální sloveso atd.) byla segmentu přiřazena jazyková funkce. Východiskem pro anotaci jazykových funkcí byl upravený seznam funkcí a př́islušných forem doporučených pro úroveň Waystage (Van Ek \& Trim, 1991).

Anotace jazykových funkcí, stejně jako chybová anotace, byla provedena nezávisle dvěma výzkumníky. Poté byla u odlišně označkovaných segmentů hledána shoda.

\subsection{Operacionalizace proměnných a postup vyhodnocování}

Přesnost jsme definovali a vyhodnocovali na základě jednotlivých kategorií výše popsané chybové anotace. Pro každou chybovou kategorii u studenta 
jsme vypočítali podíl chyb na celkovém počtu segmentů, u kterých byla chybová anotace provedena. Tento podíl jsme vyjádřili v procentech.

Hodnoty zkoumaných proměnných byly nejprve zjištěny pro jednotlivé studenty a poté byly shrnuty pro celý soubor pomocí deskriptivní statistiky. Kromě toho byla určena statistická významnost změn párových hodnot pomocít-testů na hladině spolehlivosti $\alpha=0,05$. V následujícím textu uvádíme pouze průměry a statistickou významnost u zkoumaných proměnných.

Na konci výuky (v Diskusi 3) v rámci našeho empirického výzkumu očekáváme srovnatelný nebo nižší výskyt chyb ve vybraných oblastech písemného projevu studentů oproti situaci na začátku (Diskuse 1).

\section{Výsledky výzkumu}

Dříve než představíme data související se změnami $\mathrm{v}$ jazykové přesnosti u studentů, uvedeme, že celkově došlo ve sledovaném případu ke statisticky významnému zvýšení průměrného výsledku didaktického testu z 16,69 na 19,06 bodů z max. 22 bodů (podrobněji viz Tůma, 2012, s. 148).

Než se budeme podrobně zabývat výsledky výzkumu, popíšeme žákovský korpus, ze kterého výsledky analýzy vycházejí. Korpus byl zkompilován celkem z 299 diskusních prríspěvků, obsahoval 13622 slov rozdělených do 3277 segmentů, z nichž se v 932 př́padech jednalo o větný materiál, k němuž se vztahují následující výsledky.

Po označkování první třetiny oběma anotátory jsme pravidla anotace na základě specifických př́íkladů mírně upravili a zpětně jsme doplnili anotaci sporných segmentů. Pro zbývající dvě třetiny byl korpus značkován nezávisle dvěma hodnotiteli a rozdílně anotované položky jsme poté diskutovali, dokud nebyla nalezena shoda. Pro tuto druhou fázi anotace jsme vypočetli Cohenovo kappa: 0,84 (chybová anotace) a 0,99 (anotace jazykových funkcí). Obě hodnoty jsou vyšší než 0,80 , takže anotaci můžeme považovat za reliabilní (Štindlová, 2011, s. 125).

Tabulka 2 ukazuje celkové rozložení chyb ve sledovaných oblastech. Tabulka 3 uvádí rozložení morfologických chyb, které byly anotovány podrobněji a u kterých došlo celkově ke statisticky významnému nárůstu. 
Tabulka 2

Celkové výsledky chybové analýzy korpusu

\begin{tabular}{lccc}
\hline \multicolumn{1}{c}{ Kategorie } & $\begin{array}{c}\text { Diskuse 1 } \\
\text { (průměry v \%) }\end{array}$ & $\begin{array}{c}\text { Diskuse 3 } \\
\text { (průměry v \%) }\end{array}$ & Sig. \\
\hline Chyby ve formě - ortografie & 0,89 & 1,13 & 0,7152 \\
Morfologické chyby celkově & 9,08 & 14,25 & $0,0396^{*}$ \\
Lexikální chyby & 0,39 & 1,46 & 0,1200 \\
Syntaktické chyby & 3,89 & 4,81 & 0,3462 \\
\hline
\end{tabular}

$* p \leq 0,05$

Tabulka 3

Výsledky chybové analýzy korpusu - morfologické chyby

\begin{tabular}{lccc}
\hline \multicolumn{1}{c}{ Kategorie morfologických chyb } & $\begin{array}{c}\text { Diskuse 1 } \\
\text { (průměry v \%) }\end{array}$ & $\begin{array}{c}\text { Diskuse 3 } \\
\text { (průměry v \%) }\end{array}$ & Sig. \\
\hline Flexe & 1,47 & 1,44 & 0,9603 \\
Slovesný čas & 3,88 & 8,37 & $0,0173^{*}$ \\
Pomocná slovesa & 1,98 & 1,68 & 0,6095 \\
Komplexní morfologické chyby & 1,75 & 2,76 & 0,2034 \\
\hline
\end{tabular}

${ }^{*} p \leq 0,05$

Výsledky uvedené v tabulce 2 naznačují, že ve třetí diskusi došlo k nárůstu relativního počtu chyb ve všech čtyřech sledovaných chybových oblastech (chyby ve formě, v morfologii celkově, lexikální chyby, syntaktické chyby), z toho u morfologických chyb je nárůst z 9,08 \% na 14,25 \% statisticky významný $(p=0,0396)$. To může vést $\mathrm{k}$ závěru, že u studentů došlo ke zhoršení jazykové přesnosti. Toto zjištění nás vedlo $\mathrm{k}$ návratu $\mathrm{k}$ datům a analýze obsahů, které byly s nárůstem morfologické chybovosti spojeny.

Anotace korpusu nám umožnila podrobněji analyzovat morfologické chyby ve slovesném čase, u nichž celkově došlo ke statisticky významnému nárůstu z 3,88 \% na 8,37 \% ( $p=0,0173)$. Ukázalo se, že u segmentů s chybou ve slovesném čase byly $\mathrm{v}$ první diskusi nejčetnější chyby $\mathrm{v}$ segmentech vyjadřujících jazykovou funkci oznamování a vypravování, kdežto ve třetí diskusi byly nejčetnější chyby v segmentech vyjadřujících záměr. Srovnání morfologické chybovosti $\mathrm{v}$ segmentech vyjadřujících tyto dvě jazykové funkce uvádíme v tabulce 4 . 


\section{Tabulka 4}

Srovnání rozložení morfologických chyb v segmentech vyjadřujících oznamování či vypravování a záměr

\begin{tabular}{llccc}
\hline $\begin{array}{c}\text { Jazyková } \\
\text { funkce }\end{array}$ & \multicolumn{1}{c}{ Chybová kategorie } & $\begin{array}{c}\text { Diskuse 1 } \\
\text { (průměry, v \%) }\end{array}$ & $\begin{array}{c}\text { Diskuse 3 } \\
\text { (průměry, v \%) }\end{array}$ & Sig. \\
\hline Oznamování, & Morfologické chyby celkově & 7,98 & 9,87 & 0,4790 \\
vypravování & Pomocná slovesa & 0,95 & 0,94 & 0,9905 \\
& Flexe & 2,27 & 1,75 & 0,5148 \\
& Komplexní morfologické chyby & 1,01 & 3,26 & 0,0559 \\
& Slovesný čas & 3,75 & 3,92 & 0,9119 \\
Vyjadřování & Morfologické chyby celkově & 19,60 & 37,48 & $0,0368^{*}$ \\
záměru & Pomocná slovesa & 0,00 & 5,19 & 0,1288 \\
& Flexe & 0,00 & 0,00 & \\
& Komplexní morfologické & 4,96 & 3,57 & 0,6602 \\
& chyby & 14,64 & 28,72 & 0,0935 \\
\hline
\end{tabular}

${ }^{*} p \leq 0.05$

Ze srovnání rozložení morfologických chyb $\mathrm{v}$ segmentech vyjadřujících jazykovou funkci (a) oznamování, vypravování a (b) záměr v tabulce 4 je patrné, že morfologická chybovost v segmentech spojených s oznamováním a vypravováním zůstala relativně stabilní, zatímco u segmentů spojených s vyjadřováním záměru došlo ke statisticky významnému nárůstu celkových morfologických chyb (z 19,60 \% na 37,48 \%, $p=0,0368)$, přičemž nejpatrnější, i když ne statisticky významný, je nárůst podílu chyb ve slovesných časech (z 14,64 \% na 28,72 \%, $p=0,0935$ ).

Celkové zvýšení chybovosti $\mathrm{v}$ oblasti morfologie ve třetí diskusi, které je zřejmé $\mathrm{z}$ tabulky 2 , lze tedy $\mathrm{z}$ velké části vysvětlit nárůstem počtu chyb $\mathrm{v}$ segmentech vyjadřujících záměr. To mohlo být způsobeno tématem diskuse, které vyžadovalo užití prostředků vyjadřujících záměr (studenti diskutovali o svých plánech na prázdniny); naproti tomu první diskuse užití takových jazykových prostředků nevyžadovala (studenti měli za úkol se představit a zjistit, co mají ve skupině společného), což se projevuje $\mathrm{v}$ zastoupení prostředků vyjadřujících tuto funkci (v první diskusi tvořily prostředky vyjadřující záměr průměrně 3,57 \%, ve třetí diskusi 14,04\%). $\mathrm{Z}$ těchto výsledků vyplývá, že vyjadřování záměru bylo tím obsahem, který ovlivnil výstupy. Zatímco v první diskusi se vyjadřování záměru vyskytovalo okrajově, téma třetí diskuse vyjadřování záměrů přímo vyžadovalo. 
Odpověd' na výzkumnou otázku týkající se změn $v$ přesnosti tedy není jednoznačná. Přestože celkově došlo k nárůstu chybovosti ve třetí diskusi, z podrobnější analýzy (viz tabulka 4) vyplývá, že rozložení chyb z hlediska jazykových funkcí je v obou diskusích různé, a tudíž nepovažujeme získané výsledky za zcela průkazné, protože získaná data nebyla (z hlediska rozložení jazykových funkcí) srovnatelná. Z tabulky 4 vyplývá, že rozložení chyb v obou diskusích v segmentech vyjadřujících oznamování a vypravování je diametrálně odlišné od rozložení chyb v segmentech vyjadřujících záměr. Navrženou metodologii ke zjištování jazykové přesnosti kriticky hodnotíme v následující kapitole.

\section{Diskuse a závěry}

Předkládaný výzkum umožnil hlouběji proniknout do problematiky rozvíjení komunikační kompetence, konkrétně jazykové přesnosti v psaní, pomocí počítačem zprostředkované komunikace a jejího vyhodnocování pomocí analýzy žákovského korpusu. Z empirických výsledků získaných v hlavním výzkumu vyplývá, že připravené online diskusní úkoly vedly $\mathrm{k}$ rozvoji komunikační kompetence, a to jak celkově, tak i v jiných dílčích oblastech (syntaktická složitost, vnímaná plynulost projevu, používání některých jazykových funkcí), kterými jsme se $\mathrm{v}$ tomto textu nezabývali. Tento rozvoj komunikační kompetence zdůvodňujeme aktivním zapojením studentů do připravených online diskusních úkolů. Studenti četli příspěvky jiných a komunikovali s ostatními ve skupině, čímž museli sami produkovat text $\mathrm{v}$ angličtině (viz input hypothesis, interaction hypothesis a output hypothesis v kapitole 2.1).

Chybovost $\mathrm{v}$ oblasti ortografie, lexika a syntaxe byla $\mathrm{v}$ obou diskusích poměrně nízká a $\mathrm{v}$ těchto doménách nedošlo ke statisticky významným změnám, ačkoliv došlo $\mathrm{v}$ rámci zkoumaného souboru k mírnému zvýšení výskytu chyb. V oblasti ortografie můžeme interpretovat mírně vyšší výskyt chyb jako důsledek jisté uvolněnosti diskusního fóra. U studentů navíc došlo ke zvýšení vnímané plynulosti písemného projevu (Tůma, 2012), což mohlo chybovost (jak ortografickou, tak celkovou) mírně zvýšit. V tomto výzkumu jsme se př́mo nezabývali strategiemi, které studenti používali při přispívání do diskusního fóra. Další výzkum by mohl tyto výsledky dále osvětlit ${ }^{13}$.

13 Můžeme se např domnívat, že některé lexikální chyby mohly být způsobeny použitím dvojjazyčného slovníku na internetu, který neodlišuje významy uváděných překladů. Dále je možné vyslovit domněnku, že určité oblasti jazykové přesnosti mohly být zlepšeny použitím nástrojů pro kontrolu pravopisu. 
Co se týče výstupů chybové analýzy korpusu v oblasti morfologie, naše zjištění jsou v souladu s teoriemi vývoje gramatické kompetence (Lightbown \& Spada, 2006, s. 92-93): ačkoliv se celková úroveň komunikační kompetence studentů zvýšila, došlo $v$ některých oblastech gramatické kompetence ke snížení přesnosti písemného projevu. Toto je také v souladu se specifiky gramatické přesnosti na úrovni A2, v jejíž deskripci stojí, že student „používá správně některé jednoduché struktury, ale přitom se systematicky dopouští elementárních chyb - např. má sklon k zaměňování časů, zapomíná na gramatickou shodu" (SERRJ, 2002, s. 116). Výsledky však nemůžeme srovnat s jinými výsledky chybové analýzy angličtiny na této úrovni u mluvčích, jejichž mateřským jazykem je čeština, nebot' takové analýzy patrně zatím neexistují. Náš výzkum tedy přispívá $\mathrm{k}$ poznání $\mathrm{v}$ této oblasti. Konkrétním výstupem $\mathrm{z}$ tohoto výzkumu je zjištění, že z didaktického hlediska v rámci osvojování/ učení se cizího jazyka je morfologie na úrovni A2 nestabilní. Morfologická složka gramatické kompetence navíc patrně úzce souvisí s obsahem. V tomto př́padě se jednalo o třetí úkol (diskuse o plánech na prázdniny), v němž oproti prvnímu úkolu (představení se, hledání společných věcí ve skupině) obsah zahrnoval funkci vyjadřování záměru, což způsobilo u zkoumaných studentů vyšší chybovost ve slovesném čase. Z tohoto hlediska se jeví volba tématu třetí diskuse jako ne př́liš vhodná, na druhou stranu však toto téma vyhovovalo náplni a koncepci kurzu a obě diskuse se původně jevily jako srovnatelné (viz kapitola 3.1). Ve světle naší výzkumné otázky, zda se změnila přesnost studentů $\mathrm{v}$ psaní během kurzu, musíme konstatovat, že získaná zjištění nelze považovat za zcela průkazná.

Je otázkou, zda je prakticky možné zvolit dvě různá témata pro online diskusní úkoly, ve kterých by byl elicitován srovnatelný rozsah jazykových funkcí, aby byly produkované texty srovnatelné. Jiným řešením by bylo provést tentýž diskusní úkol na začátku a na konci semestru. Takové řešení však má svá úskalí - opakovaná diskuse téhož ztrácí na smysluplnosti, a navíc bylo zjištěno, že opakování stejného úkolu s odstupem vedlo k diametrálně odlišnému výkonu, patrně kvůli vnímané snadnosti při opakování téhož (Duff, 2007). Domníváme se tedy, že výsledky poukazují na omezenost použití přirozené elicitace při vyhodnocování přesnosti u mírně pokročilých studentů angličtiny (toto a další omezení možností výzkumu založeného na žákovských korpusech uvádějí např. Škodová, 2012, s. 133; Štindlová, 2012, s. 58-60). Zdá se, že v budoucím výzkumu by bylo vhodné zakomponovat do výzkumného plánu metody sběru dat založené na experimentální nebo klinické elicitaci, kde by bylo možné rozložení používaných jazykových 
prostředků a funkcí lépe ovlivňovat. Pomocí těchto metod sběru dat a tomu odpovídající analýzy by bylo možné přijmout či vyvrátit, zda u studentů na zkoumané úrovni při zvýšení celkové komunikační kompetence dojde v psaní k poklesu jazykové přesnosti ve zkoumaných chybových oblastech.

Kromě výše uvedeného je nutné zmínit, že jsme se v této studii nezabývali tím, do jaké míry mohly vstupní charakteristiky studentů ovlivnit výstupy. Ačkoliv jsme se vliv některých těchto charakteristik snažili eliminovat výběrem participantů, u nichž jsme předpokládali na konci kurzu dosažení plně rozvinuté úrovně A2 (viz kapitola 3.3) a také jsme zařadili sběr dat pro výzkumné účely až do fáze, kdy jsme předpokládali, že všichni zkoumaní účastníci budou seznámeni s technickou stránkou online diskusních úkolů, je možné, že některé další vstupní charakteristiky, např. úroveň počítačové gramotnosti účastníků nebo jejich učební styly, mohly výsledky výzkumu ovlivnit.

V této studii jsme se zabývali vyhodnocováním chybovosti v písemném počítačem zprostředkovaném projevu studentů, tedy analýzou výstupů procesů učení, která, jak jsme uvedli v úvodu, není v českém pedagogickém výzkumu zaměřeném na používání ICT ve vzdělávání často uplatňována. Komunikace zprostředkovaná počítačem se liší od čistě ústní či písemné komunikace, a tak i procesy učení založené na ní (a tedy na integraci ICT do vzdělávání) jsou odlišné od procesů učení probíhajících v kontaktní výuce ve třŕdě. Ačkoliv jsou námi získaná zjištění $\mathrm{z}$ oblasti změn $\mathrm{v}$ jazykové přesnosti $\mathrm{v}$ některých ohledech omezena, upozornili jsme na možnosti použití žákovských korpusů při zkoumání chybovosti v cizojazyčné výuce a na jejich limity. Specificky jsme připravili anotaci pro žákovský korpus angličtiny na mírně pokročilé úrovni a tento korpus jsme zkompilovali. Přitom, jak jsme uvedli v kapitole 2.3, nejsou žákovské korpusy pro anglický jazyk na této úrovni časté. $V$ obecnější rovině jsme nastínili možnosti uplatnění (aplikovaně) lingvistické metody ve výzkumu v didaktice cizích jazyků.

Zároveň jsme stručně představili jednu $\mathrm{z}$ cest, jak $\mathrm{v}$ cizojazyčné výuce reflektovatteorie osvojování cizího jazykazaložené na vstupu (input), interakci a produkci výstupu (output; viz výše a kapitola 2.1).Vjinéstudii (Tůma, v tisku) jsme upozornili na to, že obecně nejsou sociálně-konstruktivistické teorie v českém pedagogickém výzkumu v rámci využívání ICT příliš reflektovány. Přitom aplikace založené na těchto teoriích shledáváme užitečnými, nebot' z uvedených výsledků vyplývá, že u studentů došlo ke statisticky významné změně jejich celkové komunikační kompetence. 
Prezentovali jsme dílčí výsledky výzkumného projektu zaměřeného na rozvoj komunikační kompetence u studentů (viz kapitola 3.2), konkrétně přesnost písemného vyjadřování. Přesnost považujeme za důležitou komponentu písemného projevu, potažmo tedy komunikační kompetence. Je nicméně zřejmé, že cílem online diskusních úkolů byl rozvoj řečové dovednosti psaní jako celku. To znamená, že další aspekty, jako např. syntaktická složitost nebo plynulost, které zejména mohou být v takto konstruktivisticky pojaté výuce rozvíjeny, nejsou $\mathrm{v}$ tomto textu diskutovány (tyto výsledky jsou uvedeny v Tưma, 2012).

Ačkoliv jsme ve světle naší výzkumné otázky konstatovali, že některé výsledky prezentovaného výzkumu nejsou zcela průkazné, považujeme tuto studii za př́nosnou. Z didaktického hlediska jsme poukázali na to, že morfologická chybovost $\mathrm{v}$ písemném projevu studentů angličtiny na úrovni A2 (SERRJ, 2002) patrně úzce souvisí s obsahy, které jsou v této studii prezentovány formou jazykových funkcí. Z hlediska metodologického lze jako př́nos označit analýzu korpusu na úrovni A2 (SERRJ, 2002).

\section{Literatura}

Bachman, L. F. (1990). Fundamental considerations in language testing. Oxford: Oxford University Press.

Bertrand, Y. (2003). Contemporary theories and practice in education. Madison: Atwood Publishing.

Biber, D., Johansson, S., Leech, G., Conrad, S., \& Finegan, E. (1999). Longman grammar of spoken and written English. London: Longman.

Brown, H. D. (2000). Principles of language teaching and learning. White Plains: Longman.

Brown, H. D. (2003). Language assessment: Principles and classroom practice. London: Longman.

Crystal, D. (2011). Internet linguistics: A student guide. Oxon: Routledge.

Dagneaux, E., Denness, S., \& Granger, S. (1998). Computer-aided error analysis. System, 26(2), 163-174.

Duff, P. (2007). Case study research in applied linguistics. New York: Routledge.

Ellis, R. (2003). Task-based language learning and teaching. Oxford: Oxford University Press.

Ellis, R., \& Barkhuizen, G. (2005). Analysing learner language. Oxford: Oxford University Press.

Graham, C. R. (2006). Blended learning systems: Definition, current trends, and future directions. In C. J. Bonk \& C. R. Graham (Eds.), The handbook of blended learning: Global perspectives, local designs (s. 3-21). San Francisco: Pfeiffer.

Granger, S. (2008). Learner corpora. In A. Lüdeling \& M. Kytö (Eds.), Corpus linguistics: An international handbook. Volume 2. (s. 259-275). Berlin: Walter de Gruyter.

Housen, A., \& Kuiken, F. (2009). Complexity, accuracy, and fluency in second language acquisition. Applied Linguistics, 30(4), 461-473. 
Hrdlička, M. (2012). Jazyková chyba a práce s ní v jazykovém vyučování. In K. Šebesta \& S. Škodová (Eds.), Čeština - cílový jazyk a korpusy (s. 61-88). Liberec: Technická univerzita v Liberci.

Choděra, R. (2006). Didaktika cizích jazyků: Úvod do vědního oboru. Praha: Academia.

Johnson, D. W., \& Johnson, R. T. (1994). Learning together and alone. Cooperative, competitive, and individualistic learning. Massachusetts: Allyn and Bacon.

Kasíková, H. (2007). Kooperativní učení a vyučování: teoretické a praktické problémy. Praha: Karolinum.

Krashen, S., D. (1981). Second language acquisition and second language learning. Pergamon Press. Dostupné z http://www.sdkrashen.com/SL_Acquisition_and_Learning/index.html

Lightbown, P. M., \& Spada, N. (2006). How languages are learned. Oxford: Oxford University Press.

Long, M. H. (1996). The role of the linguistic environment in second language acquisition. In W. C. Ritchie \& T. K. Bhatia (Eds.), Handbook of second language acquisition (s. 413-468). London: Academic Press.

Nunan, D. (2004). Task-based language teaching. Cambridge: Cambridge University Press.

Richards, J. C., \& Rodgers, T. S. (2001). Approaches and methods in language teaching. Cambridge: Cambridge University Press.

Seidlhofer, B. (2009). Understanding English as a lingua franca. Oxford: Oxford University Press.

Selinker, L. (1984). Interlanguage. In J. Richards (Ed.), Error analysis. Perspectives on second language acquisition (s. 31-54). London: Longman.

Schiffrin, D. (1994). Approaches to discourse. Malden: Blackwell Publishers.

Skehan, P. (1998). A cognitive approach to language learning. Oxford: Oxford University Press.

Společný evropský referenční rámec pro jazyky. (2002). Olomouc: Univerzita Palackého v Olomouci.

Stern, H. H. (1983). Fundamental concepts of language teaching. Oxford: Oxford University Press.

Swain, M. (2000). The output hypothesis and beyond: Mediating acquisition through collaborative dialogue. In J. P. Lantolf (Ed.), Sociocultural theory and second language learning (s. 97-114). Oxford: Oxford University Press.

Šebesta, K. (2012a). Cesty k žákovským korpusům. In K. Šebesta \& S. Škodová (Eds.), Čeština - cílový jazyk a korpusy (s. 5-12). Liberec: Technická univerzita v Liberci.

Šebesta, K. (2012b). Parametry žákovských korpusů a CzeSL. In K. Šebesta \& S. Škodová (Eds.), Čeština - cílový jazyk a korpusy (s. 13-34). Liberec: Technická univerzita v Liberci.

Škodová, S. (2012). Nástin využití žákovských korpusů pro jazykové vyučování. In K. Šebesta \& S. Škodová (Eds.), Čeština - cílový jazyk a korpusy (s. 125-138). Liberec: Technická univerzita v Liberci.

Štindlová, B. (2011). Evaluace chybové anotace v žákovském korpusu češtiny (disertační práce). Praha: Filosofická fakulta Karlovy univerzity.

Štindlová, B. (2012). Chybové taxonomie a možnosti chybové anotace v žákovských korpusech. In K. Šebesta \& S. Škodová (Eds.), Čeština - cílový jazyk a korpusy (s. 35-60). Liberec: Technická univerzita v Liberci.

Tůma, F. (v tisku). Reflexe využití ICT ve vzdělávání v českém pedagogickém výzkumu (2005-2011). In Sborník př́spěvků 20. výroční konference ČAPV. 
Tůma, F. (2012). Developing communicative competence through online discussion tasks: Computer mediated communication and the skill of writing (disertační práce). Praha: Filozofická fakulta Karlovy univerzity.

Van Ek, J. A., \& Trim, J. L. M. (1991). Waystage 1990. Cambridge: Cambridge University Press. Willis, J. (1996). A framework for task-based learning. Harlow: Longman.

\title{
Autor
}

Mgr. František Tůma, Ph.D., Technická univerzita v Liberci,

Fakulta př́rodovědně-humanitní a pedagogická, Katedra anglického jazyka, Voroněžská 1329/1, 46001 Liberec 1, e-mail: frantisek.tuma@email.cz

\section{A corpus-based analysis of EFL learners' accuracy in writing}

\begin{abstract}
This study presents a part of results of a research project from the field of foreign language learning and teaching, in which an analysis of a learner corpus was carried out. The research project dealt with the developing of university EFL learners' communicative competence in writing in a blended learning course. The article first briefly addresses issues related to the conceptualization of developing communicative competence and measuring learners' progress in terms of accuracy. The sample comprised 18 learners in an EFL course at the CEFR (2002) A2 level, who participated in three discussion tasks conducted online, using asynchronous discussion forums. The discussions were built on social constructivist learning theories. The main research tool was a learner corpus compiled from the texts written by the students in two online discussions. The results showed that the learners' overall level of communicative competence in writing increased. The outcomes of the corpus analysis in the field of language accuracy remain, in some respects, inconclusive. The results indicate that the learners' accuracy was linked to the communicated content. The study shows one possibility of using learner corpora in research in foreign didactics and highlights some of their limitations.
\end{abstract}

Keywords: learner corpus, communicative competence, accuracy, blended learning, social constructivist learning theories 